\title{
THE HIGH GERMAN CONSONANT SHIFT
}

\author{
by Frederik Kortlandt - Leiden
}

1. Elsewhere $(1985,1988,1991)$ I have put forward a new theory on the Proto-Germanic consonant shifts. In the following I intend to show how the High German consonant shift fits into the picture. The relevant dialect material has recently become more easily accessible through Goblirsch's lucid and well-informed treatise (1994), to which the reader may be referred for further details.

2. It may be useful to recapitulate the reconstructions which I have proposed for the successive stages of development from Proto-Indo-European to Proto-Germanic. For the argumentation I refer to the articles mentioned above.

(1) Proto-Indo-European:

plain fortes $p:, t:, k: k^{\circ}$,

aspirated lenes $p^{\prime}, t^{\prime}, k^{*}, k^{\circ}$,

glottalic lenes $p^{\prime}, t^{\prime}, k^{\prime}, k^{\circ}$.

At this stage, all plosives were usually voiceless, as they are in modern Icelandic and the southern dialects of eastern Armenian. This is in agreement with the absence of a voiced counterpart to the PIE fricative *s. Initial * $p$ '- now lost its glottalic feature and merged with its fortis counterpart *p:-, e.g. Vedic píbati 'drinks', Old Irish ibid (but Latin bibit with restored reduplication). We may also assume dissimilation of $C^{\prime} \ldots C^{\prime}$ to $C^{\prime} \ldots C^{\prime}$ and assimilation of $C^{\prime} \ldots C^{\prime}$ and $C^{\prime} \ldots C^{\prime}$ to $C^{\prime} \ldots C^{\prime}$ in roots at this stage.

(2) Dialectal Indo-European:

plain voiceless $p, t, k, k^{\circ}$,

plain voiced $b, d, g, g^{\circ}$,

glottalic voiced ' $b$, ' $^{\prime},{ }^{\prime} g,{ }^{\prime} g^{\circ}$.

Apart from the development of the palatovelars, this is the system which can be reconstructed for Proto-Balto-Slavic, where the glottalic feature merged with the reflex of the PIE. laryngeals into a glottal stop, e.g. Latvian pệds 'footstep' < *pe'd-, nuôgs 'naked' < *no'g-, cf. OE fót, nacod. This is the starting-point for the Germanic developments.

(3) Verner's law: non-initial voiceless obstruents became voiced unless they were immediately preceded by the stress. As a result, the suffix of the participle in *-tó-practically merged with the formative element of the weak preterite $*_{-} d \bar{e}$-. Verner's law did not change the system of obstruents but limited the distribution of the voiceless plosives and yielded a voiced variant ${ }^{*} z$ of the phoneme ${ }^{*} s$. 
(4) Kluge's law: the initial $*_{n}$ of a stressed suffix was assimilated to a preceding consonant. This development yielded a series of geminates which were in complementary distribution with the voiceless plosives. There is no distinction between plain and glottalic geminates.

(5) Retraction of the stress in Gothic (cf. Kortlandt 1988: 9, fn. 4). As a result, ${ }^{*} z$ became a phoneme in this language, while the geminates were all but eliminated.

(6) Grimm's law: the voiceless plosives were lenited to fricatives and voicedness was lost as a distinctive feature. In Gothic, the glottalic feature was lost and the distinction of voicedness was restored, probably under the influence of its non-Germanic neighbors.

(7) Retraction of the stress in North-West-Germanic yielded the following system of obstruents:

plain fricatives $f, p, s, x, x^{\circ}$,

plain plosives $p, t, k, k^{\circ}$,

glottalic plosives ' $p$, ' $t$, ' $k$, ' $k$,

geminates $p p, t t, s s, k k, k k^{\circ}$.

The voiced fricative $*_{z}$ became $r$, the labiovelars were eliminated, and the glottalization yielded a variety of reflexes (cf. Kortlandt 1985, 1988).

3. In Scandinavia, we find a threefold reflex of the glottalization. Weakening of the glottal occlusion in West Norse yielded preaspiration, e.g. Icelandic epli 'apple', vatn 'water', mikla 'increase', hjálpa 'help', verk 'work'. Weakening of the geminates also yielded preaspirated stops in this area. Conversely, assimilation of the glottal occlusion to the following plosive gave rise to new geminates in East Norse, e.g. Swedish vecka 'week', droppe 'drop', skepp 'ship', cf. ON vika, dropi, skip, OE wice, dropa, scip. In Danish, however, the geminates merged with the preglottalized stops, which were subject to lenition with preservation of the glottal occlusion in the western dialects, giving rise to the so-called vestjysk stød, e.g. hjal'b 'hjælpe'. It appears that preservation of the glottalization in the separate languages accounts for the existence of several layers of gemination, which can now be viewed as retentions rather than innovations, e.g. ON bekkr 'brook' <*-kj-, røkkr 'dark' < *-kw-, Swedish sätta 'set' < *-tj-, English apple $<*^{*}$-pl-, bitter $<*_{\text {-tr- }}$, cf. Gothic baitrs.

4. The evidence for Proto-Germanic preglottalized stops is not limited to Scandinavian but can also be found in English and German. It is common knowledge that standard English inserts a glottal stop before a tautosyllabic voiceless plosive, e.g. lea'p, hel'p. There is no reason to assume that this is a recent phenomenon. The High German consonant shift yielded affricates and geminated fricatives, e.g. OHG pfad 'path', 
werpfan 'throw', offan 'open', zunga 'tongue', salz 'salt', wazzar 'water', kind, chind 'child', trinkan, trinchan 'drink', zeihhan 'token'. These reflexes suggest a complex articulation for the Proto-Germanic voiceless plosives from which they developed. The origin of the gemination is unexplained in the traditional doctrine. If we start from the assumption that the Proto-Germanic plosives were preceded by a glottal occlusion which is preserved in the vestjysk stød and the English glottalization, the High German consonant shift can be explained as a lenition of the plosives to fricatives with a concomitant klusilspring of the preceding glottal stop. Note that the High German consonant shift has a perfect analogue in the English dialect of Liverpool, where we find e.g. $[\mathrm{kx}]$ in can, back, which also remains unexplained in the traditional doctrine.

5. The number of geminates was increased substantially by the West Germanic gemination of all consonants except $r$ before a following $* j$, which was a comparatively recent development (cf. Kortlandt 1993):

(8) raising of $*_{e}$ to $i$ before $*_{i}$ and $*_{j}$,

(9) loss of $* j$ before $* i$,

(10) gemination before $* j$.

The absence of gemination in OHG zelit 'tells' <*-ljeti and its presence

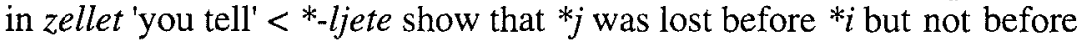
$*_{e}$ at a stage after the raising in $*_{-} e t i$. The gemination before ${ }^{*} j$ gave rise to the following system of obstruents:

simple fricatives $f, p, s, x$,

geminated fricatives $f f, p p$, ss, $x x$,

simple plosives $p, t, k$, geminated plosives $p p, t t, k k$,

simple glottalics ' $p$, 't, 'k,

geminated glottalics ' $p p$, 'tt, ' $k$.

The new geminated plosives did not merge with the Proto-Germanic geminates, which merged with the geminated glottalics instead, probably because they were longer. The glottalization was sometimes removed by analogy, e.g. in the words for 'raven' and 'roe' (cf. Lühr 1988: 332). Examples of geminated obstruents: OE skeppan 'injure', cyssan 'kiss', hliehhan 'laugh', hebban 'raise', biddan 'pray', lecgan 'lay', scieppan 'create', settan 'set', leccan 'moisten'. As Goblirsch has shown (1994: 11 and passim), the distinction between the plain and glottalic plosives, or lenes and fortes, is generally reflected as consonantal length in the modern languages, while voicedness and aspiration are concomitant features. Air pressure and muscular tension do not offer a reliable criterion because in Danish, lenis stops "have a greater tension than the fortes, which sounds like a terminological paradox" and in Icelandic, "unaspirated fortis and lenis stops were found to be tense 
compared to the aspirated fortes. In the studies on these two languages, the lack of firm closure associated with the aspirated stops was considered the decisive factor" (Goblirsch 1994: 9). In my view, a lack of firm closure in the latter part of the glottalic plosives was the origin of the High German consonant shift.

6. The glottalic plosives were lenited to fricatives with concomitant oralization of the glottal occlusion:

(11) High German consonant shift.

The new dental fricative, which I shall write $z$, remained distinct from the earlier alveolar fricative $s$. After a vowel, simple $p f, t z, k x$ became $f f$, $z z$, $x x$, e.g. OHG. offan 'open', wazzar 'water', zeihhan 'token'. The interdental fricatives $p, p p$ were subsequently shortened to $t, t t$. The full range of geminates is preserved e.g. in the North Tyrol dialect of Imst (cf. Goblirsch 1994: 35): roIpp' 'Rabe', hitt' 'Hütte', prukk' 'Brücke', kxouff' 'kaufen', hoIIass' 'heißen', loIIxx' 'lachen', huppf' 'hüpfen', sitts' 'sitzen', deNkkx' 'denken'. This is undoubtedly an archaism because the same is found in the isolated pockets of South Bavarian speech in Italy and former Yugoslavia (cf. Goblirsch ibidem and map 5 on p. 43). When " $p, k$ became $b, g$ " as a result of the High German lenition, this was not "a partial reversal of the second consonant shift" (Goblirsch 1994: 36), but of Grimm's law, when distinctive voicing was lost. Similarly, the South Alemannic "strongly geminating" dialects have preserved an archaism. The geographical distribution of the "final strengthening" in Bavarian and Alemannic (Goblirsch 1994: 43, 45) shows that this is a retention, not an innovation, and must be compared with the same phenomenon in Icelandic (e.g. Haugen 1941: 101). The same holds for the alleged strengthening of initial obstruents in the North Bavarian dialects of Bohemia and Egerland, e.g. prō'd 'breit', tum 'dumm', toxx 'Tag', kèm 'geben', and the Middle Bavarian dialects of Burgenland, e.g. pām 'Baum', taitšs 'deutsch', tō 'Tag', krāw 'grau' (cf. Goblirsch 1994: 33). These peripheral dialects have preserved a precious archaism (cf. also Goblirsch 1994: 78f.).

7. The position taken here differs from Vennemann's (cf. especially $1988,1991,1994)$ in several respects. It is closer to the traditional doctrine in dating the High German consonant shift unambiguously after the West Germanic gemination, which I regard as its impulse. While I agree with Vennemann's "repression theory" (1994: 280f.), according to which the High German system of obstruents was gradually eliminated from north to south as a consequence of Franconian rule, I do not share his assumption of an early split between High German and the rest of the Germanic language family. If the High German affrication had preceded the West Germanic gemination we 
would expect the Proto-Germanic geminates to have merged either with the simple fortes, as they in fact may have in Gothic, or with the geminated lenes, and the geminated fortes with the geminated fricatives In my view, OHG helpfan differs from Vestjysk hjal'b in the oralization of the glottal occlusion and the frication rather than voicing of the obstruent which is found in English hel'p.

\section{References}

Goblirsch, KG 1994 Consonant strength in Upper German dialects (= NOWELE, supplement vol 10) Odense

Haugen, E 1941 "On the consonant pattern of modern Icelandic", in Acta Lingustica 2, 98-107

Kortlandt, F 1985 "Proto-Indo-European glottalic stops The comparatıve evidence", in Folia Lingulstica Historica 6/2, 183-201

- 1988 "Proto-Germanic obstruents", in ABaG 27, 3-10

- 1991 "Kluge's law and the rise of Proto-Germanic geminates", in $A B a G 34$, $1-4$

- 1993 "Old High German umlaut", in $A B a G 37,19-20$

Luhr, R 1988 Expressivttat und Lautgesetz im Germanischen Heidelberg

Vennemann, Th 1988 "Die innergermanische Lautverschiebung und die Entstehung der germanıschen und deutschen Dialekte", in Languages and cultures Studies in honor of Edgar C Polomé, Berlın, 749-761

- 1991 "The relatıve chronology of the High Germanic consonant shift and the West Germanic anaptyxis", in Diachronica 8, 45-57

- 1994 "Dating the division between High and Low Germanic A summary of arguments", in Language change and language structure, Berlin, 271-303 